\title{
Reliability of Rain-Fed Maize Yield Simulation Using LARS-WG Derived CMIP5 Climate Data at Mount Makulu, Zambia
}

\author{
Charles Bwalya Chisanga ${ }^{1,2}$, Elijah Phiri \& Vernon R. N. Chinene ${ }^{2}$ \\ ${ }^{1}$ Ministry of Agriculture, Ndola, Zambia \\ ${ }^{2}$ School of Agricultural Sciences, Department of Soil Science, University of Zambia, Lusaka, Zambia \\ Correspondence: Charles Bwalya Chisanga, Ministry of Agriculture, Box 70232, Ndola 10101, Zambia. Tel: \\ 260-955-885-667. E-mail: cbchisanga@gmail.com
}

Received: November 18, 2019

Accepted: August 2, $2020 \quad$ Online Published: October 15, 2020

doi:10.5539/jas.v12n11p275

URL: https://doi.org/10.5539/jas.v12n11p275

\begin{abstract}
The impact of climate change on crop growth and yield can be predicted using crop simulation models. A study was conducted to assess the reliability and uncertainty of simulated maize yield for the near future in $2050 \mathrm{~s}$ at Mount Makulu (latitude $=15.550^{\circ} \mathrm{S}$, longitude $=28.250^{\circ} \mathrm{E}$, altitude $=1213 \mathrm{~m}$ ), Zambia. The Long Ashton Research Station Weather Generator (LARS-WG) was used to generate baseline (1980-2010) and future (2040-2069) climate scenarios for two Representative Concentration Pathways (RCP 4.5 and RCP 8.5). Results showed that mean temperature would increase by $2.09^{\circ} \mathrm{C}(\mathrm{RCP} 4.5)$ and $2.56^{\circ} \mathrm{C}(\mathrm{RCP} 8.5)$ relative to the baseline (1980-2010). However, rainfall would reduce by $9.84 \%$ (RCP 4.5) and 11.82\% (RCP 8.5). The CERES-Maize model simulated results for rainfed maize growth showed that the simulated parameters; days after planting (DAP), biomass and grain yield would reduce from 2040-2069/1980-2010 under both RCP4.5 and RCP8.5 scenarios. The LARS-WG was successfully for our location can be used in generating climate scenarios for impact studies to inform policy, stakeholders and decision makers. Adaptation strategies to mitigate for the potential impact of climate change includes several sowing dates, cultivar selection that are efficient at using nitrogen fertilizer and planting new cultivars breeds that will thrive under low root soil water content and higher temperatures.
\end{abstract}

Keywords: CERES-Maize, climate change, crop models, GCMs, IPCC, statistical downscaling

\section{Introduction}

Climate change and climate variability are affecting agriculture, energy, water resources, and hydrology, health (Fernandes et al., 2011). Increasing $\mathrm{CO}_{2}$ levels, rising temperature, and variability in precipitation amounts and patterns are affecting crop growth and yield. Climate change is defined as a statistically significant variation in either the mean state of the climate or in its variability, persisting for an extended period, which may be due to natural variability or as a result of human activities (IPCC, 2013). Climate variability refers to the climatic parameter of a region varying from its long-term mean (AMCEN, 2011). The characteristics of climate change are extreme weather events and an increase in climate variability (Manyeruke \& Mhandara, 2013; Semenov \& Stratonovitch, 2015; ZaAS, 2013). Global Climate Models (GCMs) from the Intergovernmental Panel on Climate Change (IPCC) are tools used for representing future climate conditions. Still, their coarse spatial resolution $(100-300 \mathrm{~km})$ is at a large scale to assess impacts in agriculture production systems (Osman et al., 2014). As a consequence, there is a need to bridge the gap between the large scale variables (predictors) and local scale variables (predictands). Downscaling techniques try to adapt the coarse GCM (50-400 km) output to the local level scale of a given region (Sen, 2010).

Maize (Zea mays L.) is a significant cereal crop after wheat and rice cultivated in warmer temperate and humid subtropical regions by small-holder and commercial farmers (Lukeba et al., 2013; Nurudeen, 2011). It is used by humans, livestock, and as a raw material in some industrial products. In sub-Saharan Africa, the absence of adaptive capacities and inter-seasonal rainfall variability amongst smallholder farmers are limitations in rain-fed agricultural production (Waongo et al., 2015). The Fifth Assessment Report by IPCC noted that an increase of temperature by $4{ }^{\circ} \mathrm{C}$ or more in the 21 st century poses risks on global food security, and this requires an interdisciplinary and integrated approach. A comprehensive assessment of the impact of climate change on crop growth and yield is vital to inform planners and policy makers. It is estimated globally, that projected changes in 
temperature and rainfall would reduce maize production from 3-10\% by 2050 (Thornton \& Cramer, 2012). Globally, $80 \%$ of land under agriculture is rainfed (Turral et al., 2011). However, $70 \%$ of the world population that inhabits $80 \%$ of agricultural lands are poor due to low and variable productivity (Alemaw \& Simalenga, 2015). The impact of climate change on maize yield has been studied extensively worldwide. Two approaches are usually used: crop simulation models and statistical downscaling tools. Crop simulation models consider the baseline and future effects of climate change on crop yield.

There are two downscaling techniques that are used: dynamical and statistical. Dynamical downscaling techniques (10-50 km) are used to solve the governing equations of the atmosphere on a finer grid numerically, while statistical downscaling tools are used to establish empirical relationships between local (predictands) and large-scale (predictors) variables (Hughes et al., 2014). There are three types of statistical downscaling types, namely: weather classification, regression models, and stochastic weather generators (Wilby et al., 2004; Wilby \& Dawson, 2004). In statistical downscaling, 20-35 years of daily observed weather records are required as it provides the full variability of the observed climate and allows the downscaling tools to better model climate changes (Mckague et al., 2005). A computationally inexpensive statistical downscaling tool used in generating local scale climate scenarios based on global or regional climate models for impact assessments of climate change is the Long Ashton Research Station Weather Generator (LARS-WG). LARS-WG has been well validated in under different climates around the world, including Zambia (Chisanga et al., 2017; Semenov et al., 1998; Wang, 2015). (Semenov et al., 1998) noted that LARS-WG should be evaluated to ensure that the generated synthetic data are suitable for the intended use. Climate change impact assessments are usually undertaken at a large spatial scale. As a result, local-scale impact and adaptation potentials under which farmers operated are not taken into consideration.

The changes in meteorological parameters on crop growth and yield can be studied using stochastic weather generators and crop models. LARS-WG has been used to generate climate scenarios as inputs into the Sirius wheat and STICS models (Butterworth et al., 2009; Evans et al., 2010; Semenov et al., 2009, 2007). The literature reviewed indicated insufficient research on the local-scale impact of climate change and variability using climate scenarios generated using LARS-WS as inputs into the CERES-Maize model. The climate scenarios generated using LARS-WG can be used in crop yield forecasting and in hydrological modeling. The LARS-WG can be used to provide real-time transient climate scenarios for forecasting crop growth and yield in Zambia. Linking a stochastic weather generator (LARS-WG) to crop models has been proposed by (Wang, 2015). The CERES-Maize model has been evaluated at field level and in many countries (Chisanga et al., 2015; Gaydon et al., 2012; Tsimba et al., 2013) and it is a widely used reference maize model (Lizaso et al., 2011). The CERES-Maize model has been used in exploring new cultivar potential and optimum sowing dates without carrying out costly field experiments (Bationo et al., 2012; Chisanga et al., 2015; Soler et al., 2005). The study objectives were: to identify the temperature and rainfall trends for Mount Makulu; and to investigate the reliability of rainfed maize yield using 3 CMIP5 GCMs and CERES-Maize model at Mount Makulu, Zambia.

\section{Materials and Methods}

\subsection{Description of the Study Site and Weather Data}

Mount Makulu Central Research Station, Zambia (latitude $=15.550^{\circ} \mathrm{S}$, longitude $=28.250^{\circ} \mathrm{E}$, altitude $=1213 \mathrm{~m}$ ) is located in Chilanga, off Kafue road in Agro-Ecology Region II (AERII). Its climate described as a wet and dry tropical and sub-tropical and is modified by altitude (MTENR, 2010). The climatic class for Mount Makulu, according to Koeppen Climate Class is Warm Temperate Climate with dry winter and hot summer (Cwa). The site receives between 800 to $1,000 \mathrm{~mm}$ of annual rainfall and represents $42 \%$ of the country. The observed weather data for the baseline (1980-2010) was obtained from the Agricultural Modern-Era Retrospective Analysis for Research and Applications (AgMERRA) Climate Forcing Dataset for Agricultural Modeling (Ruane et al., 2015). The AGMERRA data is stored at $0.25^{\circ} \times 0.25^{\circ}$ horizontal resolution $(\sim 25 \mathrm{~km})$, with global coverage. The baseline (1980-2010) is of particular importance for agricultural modeling efforts due to the necessity to calibrate models for improved inter-comparison and can be used to statistically and dynamically construct future climate scenarios.

\subsection{Description of DSSAT-CERES-Maize Model}

The Decision Support Systems for Agrotechnology Transfer (DSSAT) version 4.6 (Hoogenboom et al., 2010; Jones et al., 2010, 2003) was used in this study. The DSSAT-CERES (Crop Environmental Resource Synthesis) Maize model is a process-oriented, management level model designed to simulate maize phenology, dry matter partitioning, yield, root-soil water, soil temperature, and nitrogen dynamics at a field scale on a daily time step 
from inputs of climate data, management, genotype and soil (Jones \& Kiniry, 1986; Jones et al., 2003; Keating et al., 1988).

\subsection{Description of $L A R S-W G$}

The Long Ashton Research Station Weather Generator (LARS-WG) is a stochastic weather generator which can be used for the simulation of weather data at a single site for the baseline and future climate conditions (Racsko et al., 1991; Semenov et al., 1998; Semenov \& Brooks, 1999). LARS-WG uses the semi-empirical distributions for the lengths of daily solar radiation, daily rainfall, and wet and dry day series (Semenov \& Barrow, 2002). Daily weather data of 30 years is recommended to determine robust statistical parameters (Mckague et al., 2005). Daily minimum and maximum temperatures are considered as stochastic processes with daily means and daily standard deviations conditioned on the wet or dry status of the day. The seasonal cycles of means and standard deviations are modelled by finite Fourier series of order three and the residuals are approximated by a normal distribution. The Fourier series for the mean is fitted to the observed mean values for each month (Semenov \& Stratonovitch, 2015). LARS-WG uses a semi-empirical distribution to model solar radiation. More details on LARS-WG are provided by Semenov et al. (1998), Semenov and Barrow (2002, 1997), and Semenov and Stratonovitch (2015).

\subsection{Generating the Baseline and Future Climate Scenarios}

The process of generating local-scale daily climate scenario data using LARS-WG v6 is divided into two steps: Site Analysis; and Generator (Semenov and Barrow, 2002; Semenov and Stratonovitch, 2010). The baseline data (observed station data [1980-2010] were used to perform site analysis and to generate synthetic daily weather data using three global climate models (GCMs) (HadGEM2-ES, MIROC5, and MPI-ESM-MR) (Semenov \& Stratonovitch, 2015) under two Representative Concentration Pathways (RCP4.5 and RCP8.5) shown in Table 1. The sit parameter file created under Site Analysis was used by the Generator in LARS-WG to generate 30 years of synthetic daily precipitation, minimum and maximum temperature for Mount Makulu for the time slice 1980-2010 and 2040-2069 under RCP4.5 and RCP8.5. The baseline synthesis weather data statistically resembled the observed station weather data.

Table 1. Coupled Model Intercomparison Project Phase 5 (CMIP5) subset GCMs considered under AgMIP

\begin{tabular}{lllll}
\hline Modeling Centre & Country & Model & Grid resol & Res \\
\hline Met Office Hadley Centre & UK-Exeter & HadGEM2-ES & $1.25 \times 1.88$ & MR \\
$\begin{array}{l}\text { Atmosphere and Ocean Research Institute (University of Tokyo), } \\
\begin{array}{l}\text { National Institute for Environmental Studies and Japan Agency } \\
\text { for Marine-Earth Science and Technology }\end{array}\end{array}$ & & MIROC5 & $1.39 \times 1.41$ & HR \\
Max Planck Institute for Meteorology (MPI-M) & Germany & MPI-ESM-LR & $1.85 \times 1.88$ & MR \\
\hline
\end{tabular}

\subsection{Plant Materials}

The maize cultivars, PHB 30G19, PHB 30B50, and ZMS 606 are medium maturity of 120-130 days. PHB30B50 is recommended to be grown under irrigation while PHB30G19 and ZMS 606 can be grown under irrigated and rainfed conditions in Zambia, respectively. PHB30G19 and PHB30B50 are white and yellow cultivars, respectively, produced by Pioneer. The ZMS 606 is excellent drought tolerance maize caltivar. The selected cultivars have a long commercial life, adaptability, good heat, and drought resistance, and they can be applied in different locations at local-scale using crop simulation models.

\subsection{Simulating Crop Growth and Yield}

The precipitation and temperature annual means were computed using a multi-model ensemble under RCP4.5 and RCP8.5 scenarios. The synthetic time series ensemble data were used as inputs into the CERES-Maize model version 4.7. The crop model was used to simulate maize growth and grain yield using the baseline (1981-2010) and future (2040-2069) climate scenarios. Three maize cultivars, three sowing dates (PDs), and three nitrogen fertilizer levels (120 [N1], 240 [N2] and 360 [N3] kg/ha NPK 10-20-10 [N, $\left.\left.\mathrm{P}_{2} \mathrm{O}_{5}, \mathrm{~K}_{2} \mathrm{O}\right]\right)$ were applied as a basal dressing at the date of sowing. The 120 (N1), 240 (N2) and 360 (N3) kg urea (46\% N) was applied as a top dressing. A calibrated and validated CERES-Maize model was used to run the simulation using seasonal analysis. 


\subsection{Data Analysis}

The observed and synthetic (generated) weather data for the baseline were compared using Kolmogorov-Simirnov (K-S) test (Equation 1), T-test (Equation 2), and F-test (Equation 3). The K-S test, T-test, and F-test were used to compare the probability distribution, means, and standard deviations, respectively. The coefficient of determination $\left(\mathrm{R}^{2}\right)$ of a linear regression model is the quotient of the variances of the observed (obs) and generated (gen). The K-S, T-test, F-test, and $\mathrm{R}^{2}$ were computed using Equations 1, 2, 3, and 4 below, respectively:

$$
\mathrm{D}=\operatorname{Maximum}\left|\mathrm{F}_{\mathrm{n} 1}(\mathrm{X})-\mathrm{F}_{\mathrm{n} 2}(\mathrm{X})\right|
$$

where, $\mathrm{n}_{1}=$ observed data, $\mathrm{n}_{2}=$ generated data.

$$
\mathrm{t}=\frac{\overline{\mathrm{x}}_{1}-\overline{\mathrm{x}}_{2}}{\sqrt{\frac{\mathrm{s}_{1}^{2}}{\mathrm{n}_{1}-1}-\frac{\mathrm{s}_{2}^{2}}{\mathrm{n}_{2}-1}}}
$$

where, $\bar{x}_{1}$ and $\bar{x}_{2}$ are the means of the two datasets (observed and generated), $\Delta$ is the difference between the population means ( 0 if testing for equal means), $s_{1}^{2}$ and $s_{2}^{2}$ are the standard deviations of the two datasets, and $n_{1}$ and $n_{2}$ are the sizes of the two dataset. The number of degrees of freedom for the problem is smaller of $n_{1}-$ 1 and $n_{2}-1$.

$$
\mathrm{F}=\frac{\mathrm{s}_{1}^{2}}{\mathrm{~s}_{2}^{2}}
$$

where, $s_{1}^{2}$ is variance of the observed data; $s_{2}^{2}$ is variance of the generated data.

$$
\mathrm{R}^{2}=\frac{\sum\left(\widehat{\mathrm{G}}_{\mathrm{i}}-\overline{\mathrm{G}}\right)^{2}}{\sum\left(\mathrm{O}_{\mathrm{i}}-\overline{\mathrm{O}}\right)^{2}}
$$

where, $\mathrm{O}_{\mathrm{i}}$ is denoted as the observed values, $\overline{\mathrm{O}}$ and $\overline{\mathrm{G}}$ as the means of the observed and generated values.

Standard deviation (SD), coefficient of variation ( $\mathrm{CV}=\mathrm{SD} /$ mean), and mean were calculated for the baseline, RCP4.5 and RCP8.5 30-year simulation. These metrics were used to assess inter-annual maize yield variability. Smaller CVs or SDs corresponded to low risks linked to climate change.

\section{Results and Discussion}

\subsection{Calibration of LARS-WG}

Long Ashton Research Station Weather Generator (LARS-WG) version 6 incorporates climate projections from the multi-model ensembles of GCMs used in the Fifth Assessment Report of the Intergovernmental Panel on Climate Change (IPCC). LARS-WG version 6 integrates baseline (1980-2010) site parameters (Semenov and Stratonovitch, 2015). In LARS-WG, the GCMs are not directly applied, but the models apply proportionally local station climate parameters (rainfall, temperature and solar radiation) which are adjusted based on relative monthly changes in rainfall amount, daily wet and dry series duration, mean temperature and standard deviation between the baseline and future climate predicted by a GCM (Hassan \& Harun, 2013; Khan et al., 2006). Local site climate parameters are adjusted proportionately to represent climate change (Khan et al., 2006).

\subsection{KS-Test for Seasonal Distributions: Effective N, KS Statistic and p-Value at Mount Makulu}

The suitability of LARS-WG v6.0 in simulating rainfall, temperature and solar radiation are shown in Figures 1 and 2. The K-S statistics for seasonal wet/dry and daily rainfall distribution were fitted well by the LARS-WG v6.0 used in this study for DJF (wet/dry), MAM (dry), JJA (dry), and SON (dry) and JFMAMJJAOND (Figure 1). Nonetheless, the performance of LARS-WG used in this study was poor for seasonal wet (MAM and JJA) and daily rainfall distribution (September) due to lack of rainfall in those months. The LARS-WG v6.0 used in this study is capable of simulating the seasonal distributions of the wet/dry spells and daily rainfall distributions for Mount Makulu. Similar results have been reported by Chisanga et al. (2017), Hassan et al. (2014) and Qian et al. (2004). Temperature and solar radiation parameters were accurately simulated as shown in Figures 2a, 2b, 2c, and $2 \mathrm{~d}$. Stochastic weather generators generate synthetic weather data that have statistical properties similar to the observations (Qian et al., 2004). A study by Chisanga et al. (2017) also found similar results and are in agreement with the findings of this study. A study by Wang (2015) in Korea concluded that data generated by the LARS-WG reflected the regional climate characteristics very well. The LARS-WG has been applied in countries such as the United States, Canada, Europe, Asia and Africa (Chisanga et al., 2017; Hassan \& Harun, 2013; Heydari et al., 2013; Qian et al., 2005; Semenov et al., 1998; Semenov \& Brooks, 1999). Their findings revealed that the weather generator performed well in distributing the wet and dry series. It has also been used in climate change impact assessments at local scale. 


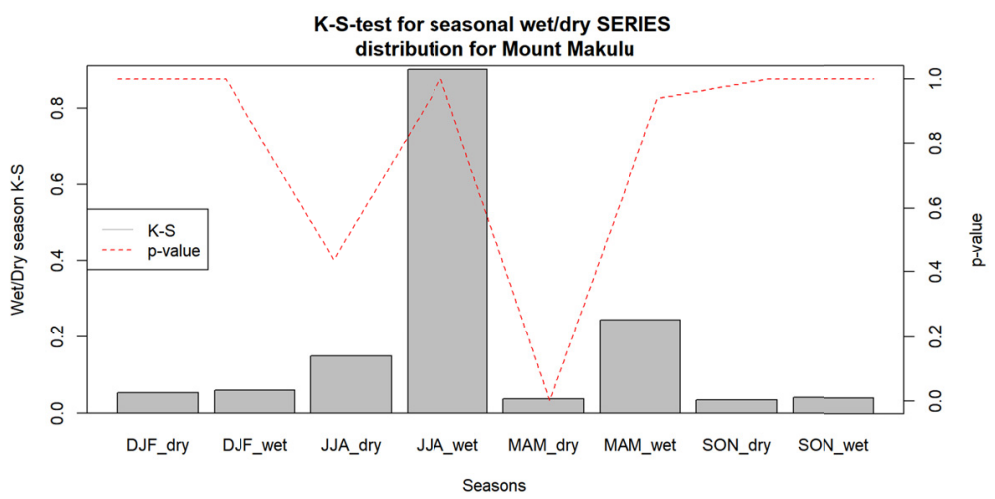

Figure 1. K-S-test for seasonal wet/dry SERIES distribution for Mount Makulu
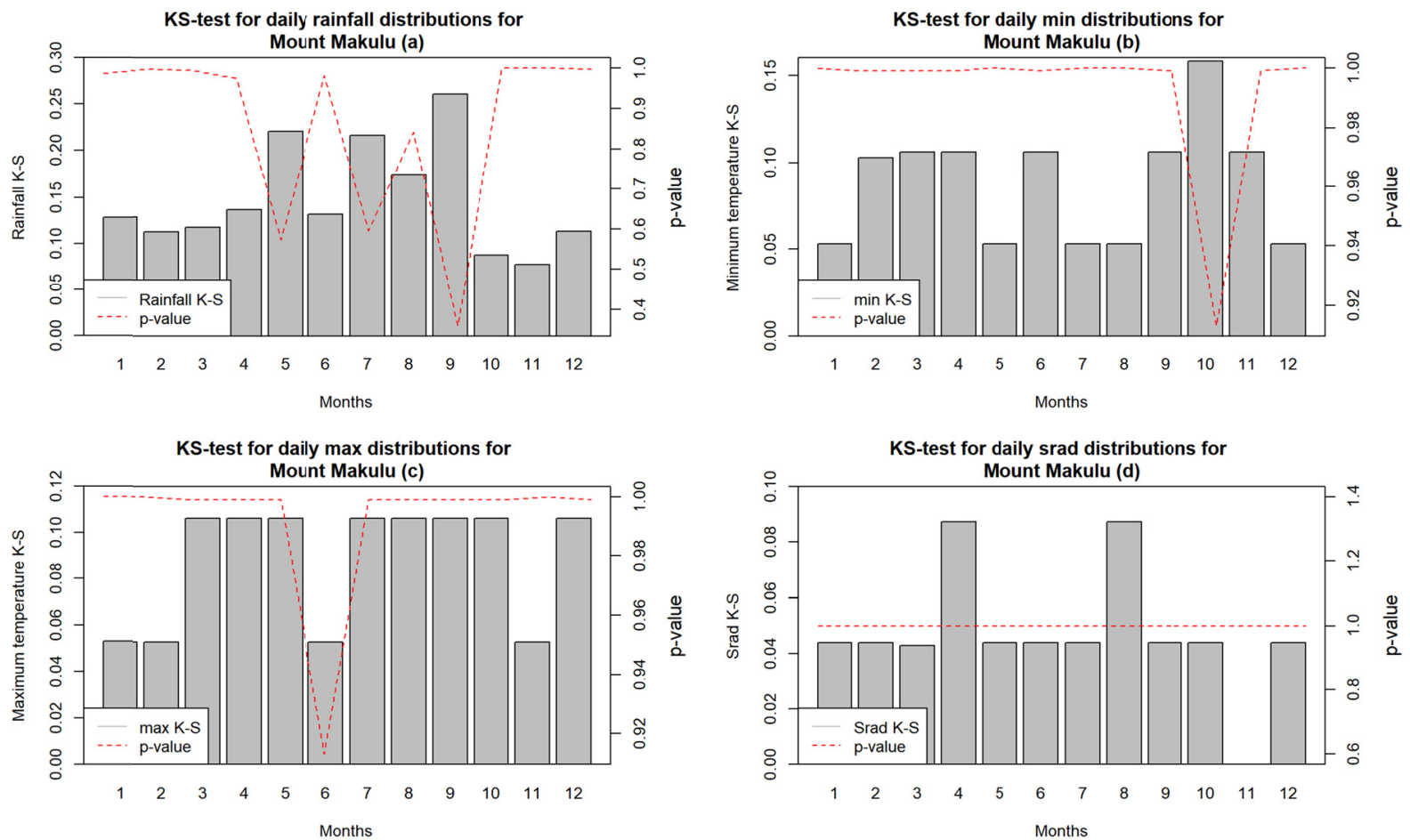

Figure 2. K-S test for daily rainfall, minimum, and maximum temperature and solar radiation distributions for Mount Makulu

\subsection{Monthly Means and Standard Deviations for Temperature, Rainfall and Solar Radiation at Mount Makulu}

Comparisons between the monthly mean and standard deviation for temperature, rainfall and solar radiation are shown in Figure 3. The results showed very good performance of LARS-WG in fitting the monthly means of temperature, rainfall and solar radiation statistics giving coefficient of determinations and correlation coefficients approximately equal to unit. The $\mathrm{R}^{2}$ for the mean monthly rainfall and temperature (tmax and tmin) and solar radiation had strong linear relationship between observed and generated (synthetic) data. The LARS-WG used in this study was able to reproduce the mean monthly solar radiation. A study by (Wang, 2015) in Korea reported similar results. The maximum and minimum temperatures generated by LARS-WG were closer to the observed baseline values. LARS-WG was able to accurately simulate mean monthly temperature and rainfall amounts for Mount Makulu. (Ababaei et al., 2010) agrees with the findings of this study in his study. He also observed that LARS-WG was able to reproduce observed values, especially daily distributions and mean monthly values.

The standard deviation showed an excellent performance for minimum temperature, solar radiation and rainfall (Figure 3). It has been observed that the means and standard deviations for daily synthetic weather data are supposed to be non-significantly different from the observations (Qian et al., 2003). It is also important that 
synthetic weather series follow a probability distribution which is not statistically different from the observed time series. The maximum temperature monthly standard deviations of the generated values were under estimated. Similar results have been reported by (Semenov et al., 1998; Semenov \& Brooks, 1999) and this is one of the limitation of LARS-WG. Maximum temperature is taken as a stochastic process where monthly means and standard deviations are conditioned on the wet or dry status of the day (Semenov et al., 1998).
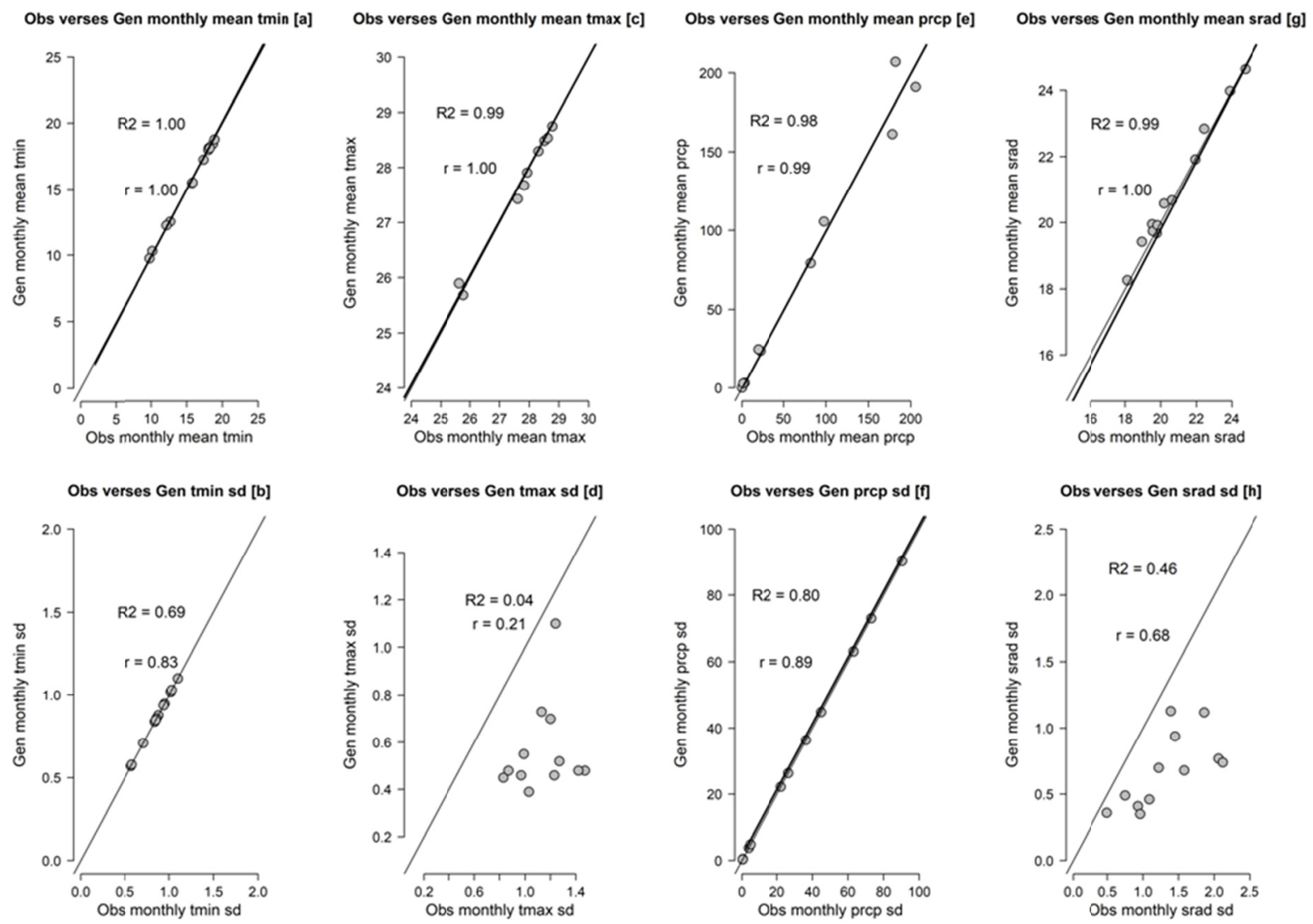

Figure 3. Monthly means and standard deviations for minimum and maxim temperature, rainfall and solar radiation at Mount Makulu

\subsection{Future Climate Scenarios}

The mean annual rainfall and temperature change were projected using 3 GCMs for 2040-2069 (RCP4.5 and RCP8.5 scenarios) relative to 1980-2010. Future climate scenarios for Mount Makulu indicate a hotter and drier climate as shown in Figure 4. The change in rainfall from 2040-2069 relative to 1980-2010 would be $-11.64 \mathrm{~mm}$ and $-15.24 \mathrm{~mm}$ under RCP4.5 and RCP8.5 scenarios, respectively. The mean temperature change relative to the baseline would be $1.81{ }^{\circ} \mathrm{C}(\mathrm{RCP} 4.5)$ and $2.46{ }^{\circ} \mathrm{C}(\mathrm{RCP} 8.5)$. Since the assumed $\mathrm{CO}_{2}$ emissions are higher under RCP8.5 (541 ppm) compared to RCP4.5 (487 ppm), there are generally higher changes in temperatures and rainfall as shown in Figure 4 and Figure 5.

Seasonal sum rainfall would also reduce under RCP4.5 $(\mathrm{JFM}=-0.81 \mathrm{~mm} ; \mathrm{AMJ}=0.56 \mathrm{~mm} ; \mathrm{JAS}=-0.02 \mathrm{~mm}$; OND $=-3.62 \mathrm{~mm})$ and RCP8.5 $(\mathrm{JFM}=0.32 \mathrm{~mm}$; AMJ $=-0.40 \mathrm{~mm} ; \mathrm{JAS}=-0.08 \mathrm{~mm}$; OND $=-4.92 \mathrm{~mm})$. However, the mean seasonal temperature would increase under RCP4.5 $\left(\mathrm{JFM}=1.46{ }^{\circ} \mathrm{C} ; \mathrm{AMJ}=1.74{ }^{\circ} \mathrm{C} ; \mathrm{JAS}=\right.$ $1.87{ }^{\circ} \mathrm{C}$; OND $\left.=2.19{ }^{\circ} \mathrm{C}\right)$ and $\mathrm{RCP} 8.5\left(\mathrm{JFM}=2.09{ }^{\circ} \mathrm{C}\right.$; AMJ $=2.54{ }^{\circ} \mathrm{C} ; \mathrm{JAS}=2.34{ }^{\circ} \mathrm{C}$; OND $\left.=2.86{ }^{\circ} \mathrm{C}\right)$. The ensemble means based on 3 GCMs showed a decrease in seasonal rainfall in under RCP4.5 (JFM and OND) and RCP8.5 (OND) (Figure 5). The projected temperature increase under both scenarios (RCP4.5 and RCP8.5) at Mount Makulu are suitable for growing maize. It has been reported that maize grows well between 15 and $35{ }^{\circ} \mathrm{C}$ (Araya et al., 2015). The projected mean temperature (19.84-28.56 ${ }^{\circ} \mathrm{C}$ [RCP4.5]; 20.24-28.76 ${ }^{\circ} \mathrm{C}$ [RCP8.5]) for Mount Makulu are within the thresholds reported by (Araya et al., 2015). A study by (Chen et al., 2012) in Sudan using LARS-WG also predicted decreasing and increasing trends in rainfall and temperature, respectively. 

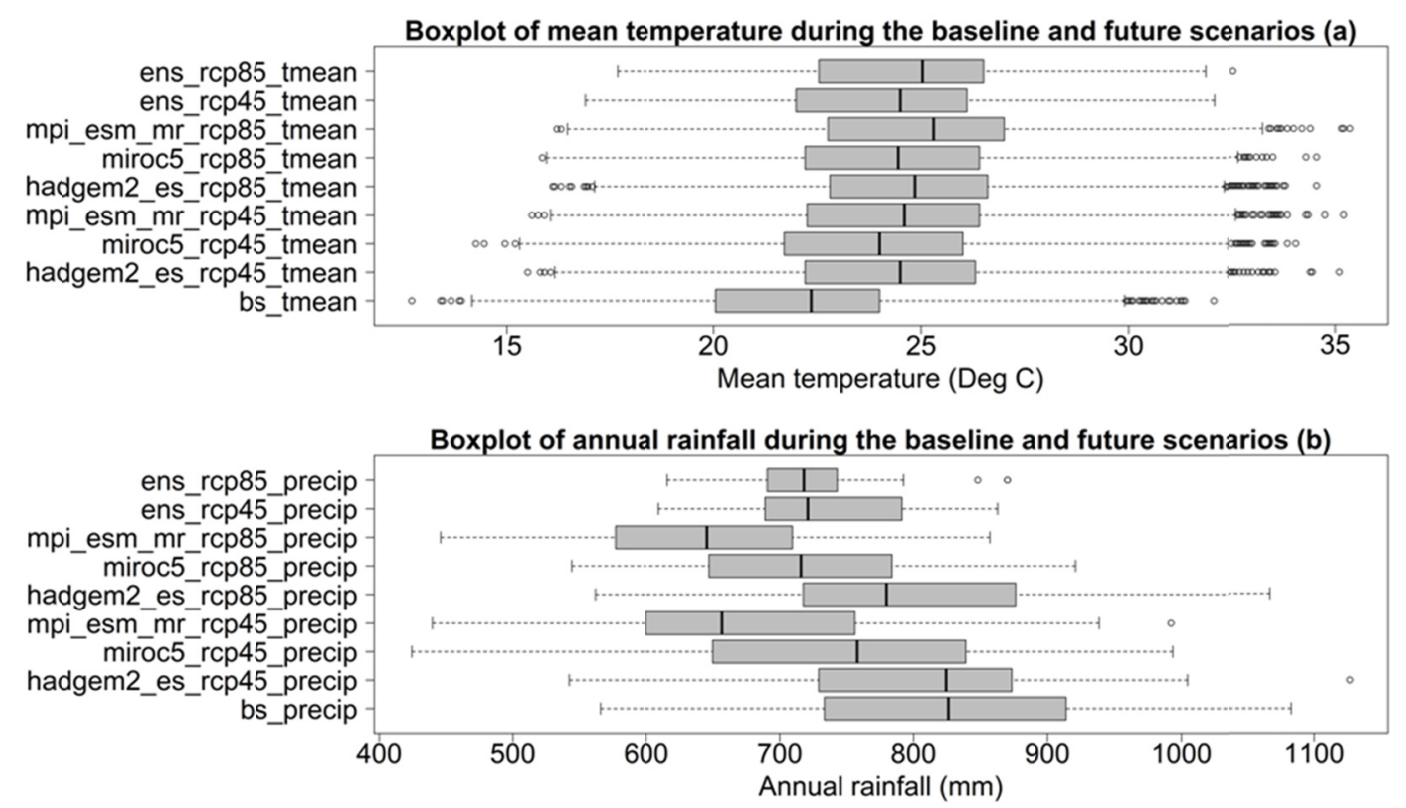

Figure 4. Boxplots of annual changes in temperature and rainfall

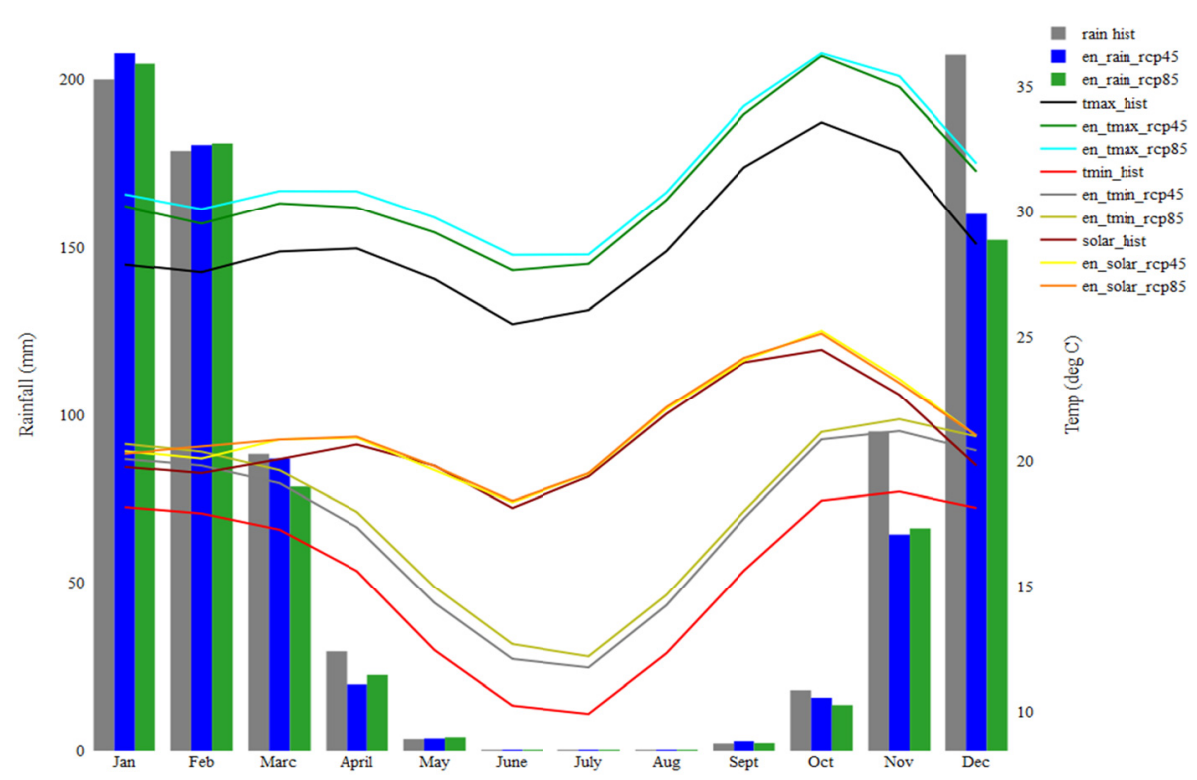

Figure 5. Comparison of monthly rainfall and temperature for baseline (1980-2010) and 2040-2069

(RCP4.5, RCP8.5) for Mt Makulu

\subsection{Impact of Climate Scenarios on Maize Yield}

\subsubsection{Phenological Stages}

Results show that the phenological stages at all treatment levels (days after planting [DAP]) would reduce relative to the baseline as shown in Figure 6 and Figure 7. The observed maize cultivar maturity ranges from 120-130 DAP. Maize growth, development and yield depends on temperature and soil water. Temperature increases lead to rapid accumulation of growing degree days and therefore, crop growth and development are faster. This results in the reduction of DAP or the duration of the phenological phase. Changes in rainfall and temperature would affect maize cultivar phenology differently. The increase in temperature and reduction in rainfall would cause the maize crop to develop faster and reach anthesis and maturity earlier during the 2050s. The simulated number of DAP during the baseline for the three maize cultivars would be different. The maize cultivars (ZMS606 $[$ anthesis $=44.57$; maturity $=101.73]$; PHB30G19 [anthesis $=46.73$; maturity $=105.3$; PHB30B50 [anthesis $=43.87$; maturity $=99.97]$ ) used in this study with longer duration to anthesis and maturity 
would experience reduced DAP in 2050s. The simulated percent reduction in anthesis and maturity for the ZMS606, PHB30G19 and PHB30B50 would be higher under RCP8.5 compared to RCP4.5 scenario as shown in Figure 6 and Figure 7. A reduction in the number of DAP to anthesis and maturity have also been observed by Lin et al. (2015) and Zhang et al. (2015).

(a)

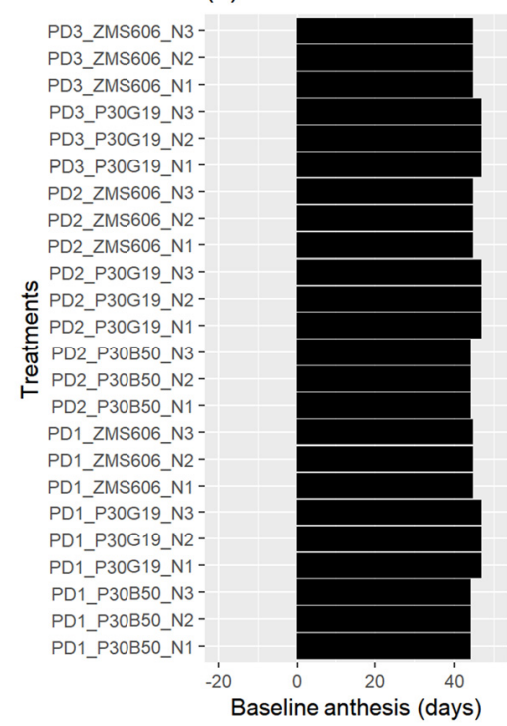

(b)

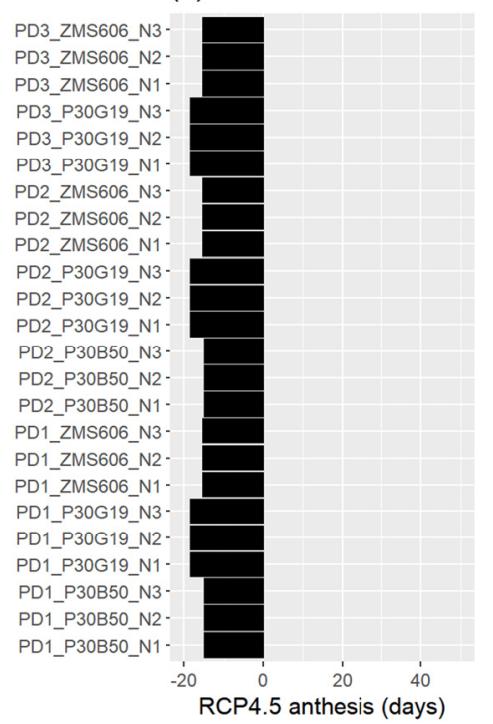

(c)

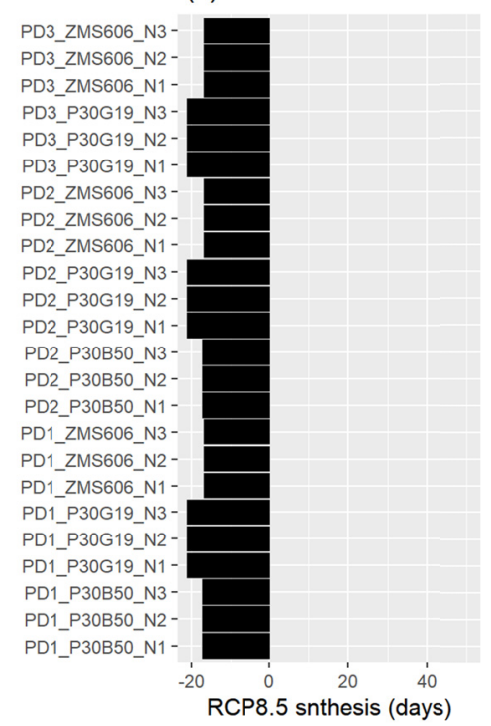

Figure 6. Projected\% change in days after planting to anthesis during 2050s (2040-2069) using CERES-Maize model relative to the baseline (1980-2010)

(a)

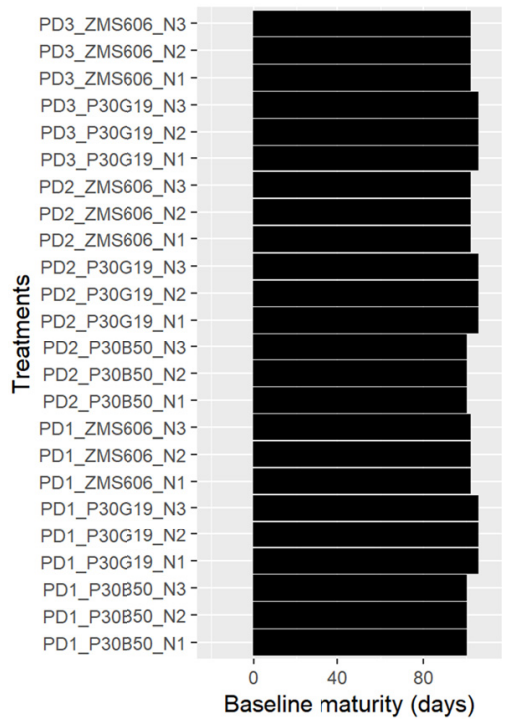

(b)

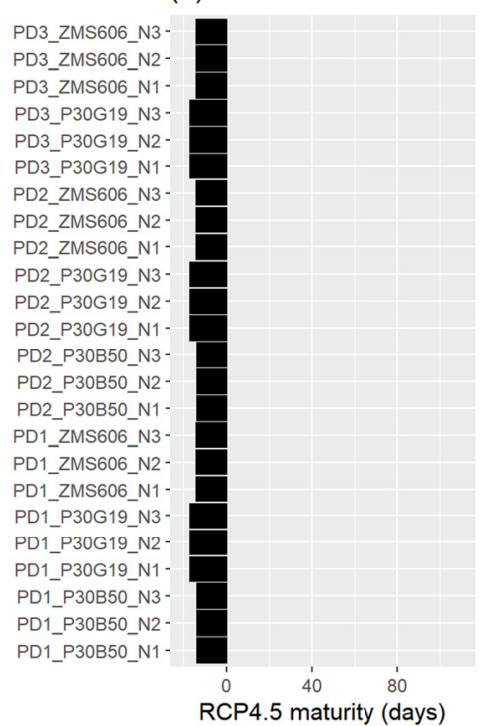

(c)

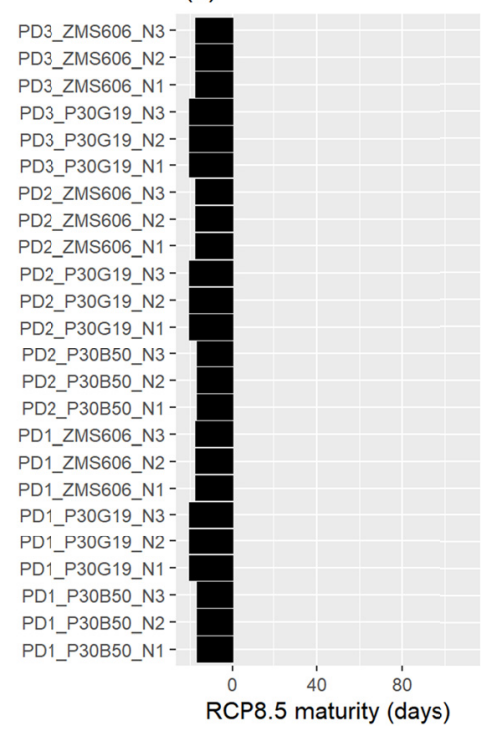

Figure 7. Projected\% change in days after planting to anthesis over 2050s (2040-2069) using CERES-Maize model relative to the baseline (1980-2010)

\subsubsection{Biomass and Grain Yield}

Results shown in Figure 8 and Figure 9 indicate that biomass and grain yield would reduce under RCP4.5 and RCP8.5 scenarios relative to the baseline. Biomass and grain yield are between the -1 and +1 standard deviation. This indicates that $68.26 \%$ of the yield values lie in the first standard deviation of the normal distribution curve. Maize cultivars (ZMS606 (-27.94 to $-18.41 \%$ [RCP4.5]; -19.99 to $-15.64 \%$ [RCP8.5]), PHB30G19 (-27.88 to $-17.68 \%$ [RCP4.5]; -18.12 to $-9.34 \%$ [RCP8.5]) and PHB30B50 (-25.32 to $-21.81 \%$ [RCP4.5]; -22.13 to $-11.13 \%$ 
[RCP8.5])) would behave differently under future climate scenarios. Two climatic factors that are directly altered by climate change and affect maize growth, development and yield are rainfall and temperature. Increased temperature in future would enable grain crops to mature more quickly and this would shorten the number of DAP to anthesis and physiological maturity resulting in reduced grain yield. Climate change induced by $\mathrm{CO}_{2}$ enrichment is likely to affect plant growth, development and yield differently depending on the cultivar. PHB30G19 would perform better under RCP8.5 compared to RCP4.5 scenarios. As discussed above, carbon dioxide enrichment in the atmosphere may enhance grain yield under RCP8.5 (541 ppm) compared to RCP4.5 (487 ppm). Rainfall and air temperature effects are accentuated under higher fertility (nitrogen fertilizer rates) compared to lower fertility as shown in Figure 8 and Figure 9. Treatments receiving lower N rates (ZMS606 and PHB30B50) would out-perform those receiving higher rates during the 2050s. Fertilizer treatment rate (N2) effect on ZMS606 and PHB30G19 would have higher reduction in grain yield compared to N1 and N2 at all sowing dates. Cultivar PHB30B50 with N3 would experience higher reduction in grain yield compared to N1 and N2. This cultivar (PHB30G50) is specifically bred to be grown under irrigation. The effects of reduced rainfall would impact on growth and yield of PHB30B50 at higher fertility compared to lower fertility.

The probability of obtaining reduced grain yields in future would make maize unsuitable economically at Mount Makulu. Projected temperature increase and rainfall variability would reduce maize yield in the range of 3-10\% globally by 2050 (Thornton \& Cramer, 2012). Projected rainfall and temperature changes would reduce maize yield in Africa as a result of reduced DAP and water stress (Adhikari et al., 2015). (Bassu et al., 2014) agrees with the findings of this study that temperature increase has negative impact on grain yield. (Soussana et al., 2010) reported that there is limited literature on studies that have focused on modeling maize cultivars with proper thermal time, crop heat units and resistant to drought to maintain productivity under a changed future climate. Reduction in rainfall would lead to fluctuation in root soil water content in future (Kang et al., 2009). Soils with higher water holding capacity would reduce the impact of drought whilst maintaining crop growth and yield. Crop yield and available soil water are likely to decrease under future climate scenarios as evapotranspiration increases under higher temperatures.

(a)

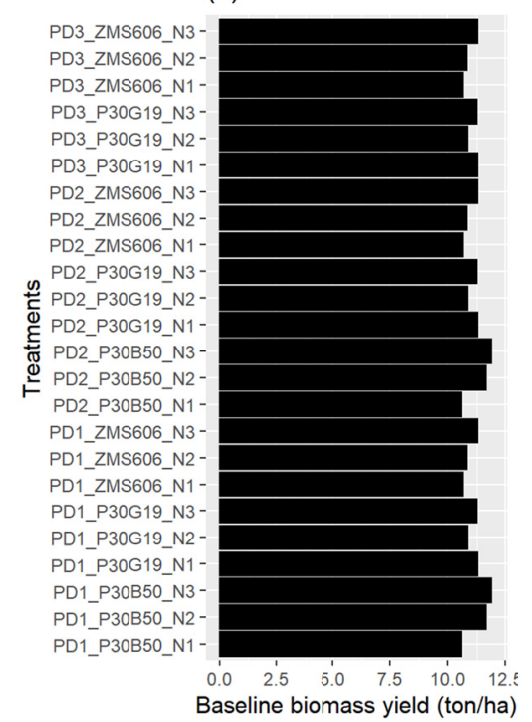

(b)

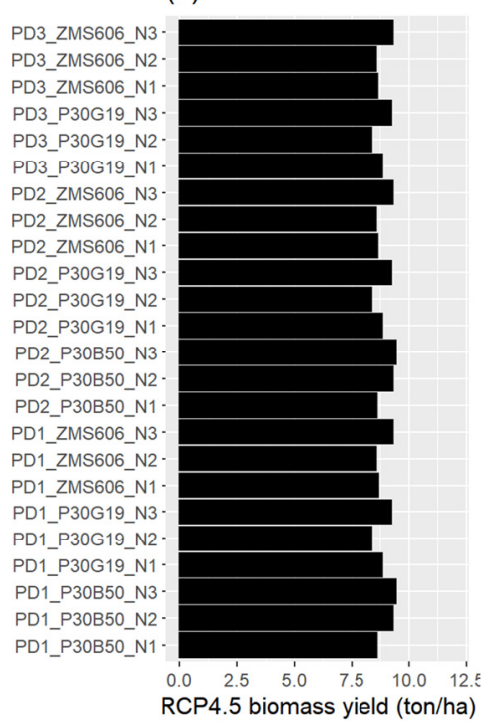

(c)

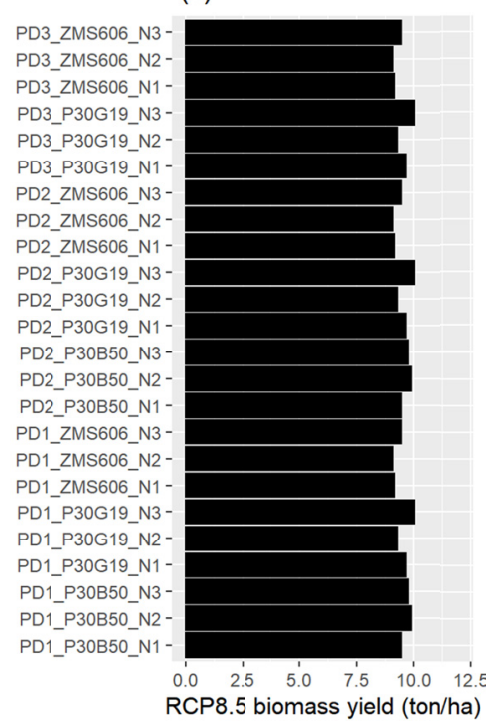

Figure 8. Projected\% change in biomass yield using CERES-Maize model in 2040-2069/1980-2010 
(a)

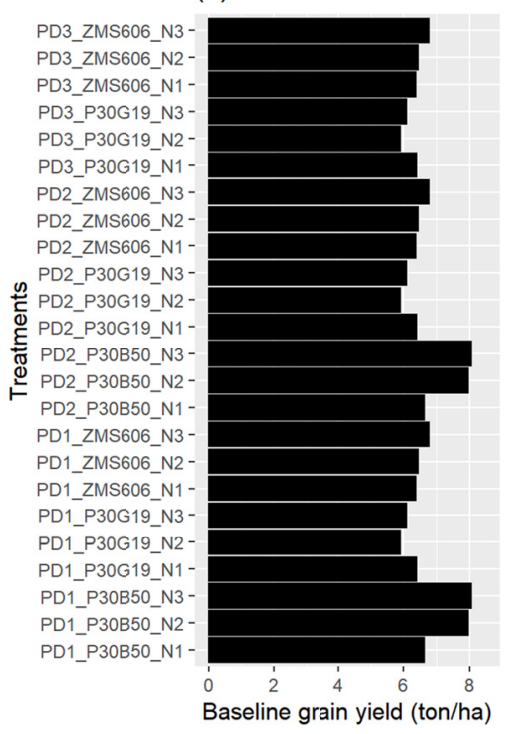

(b)

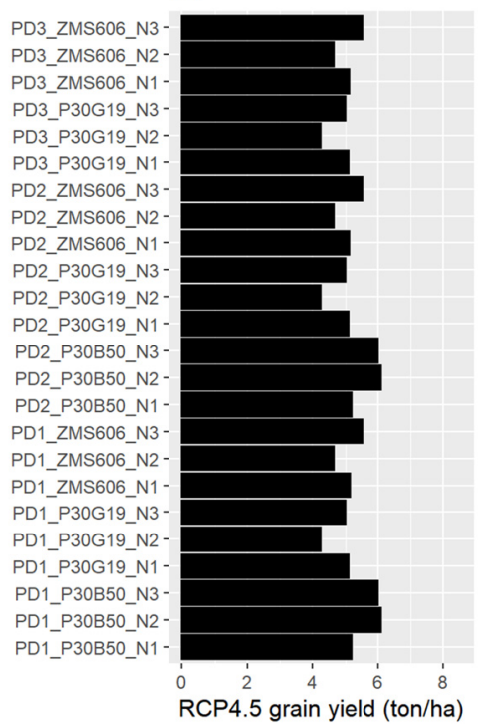

(c)

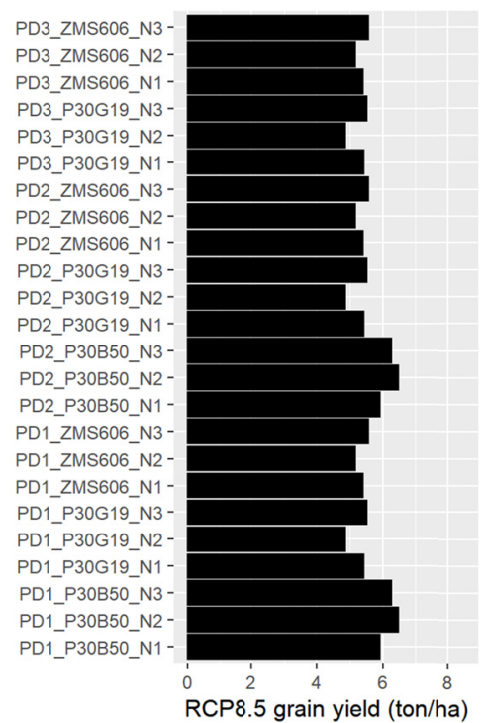

Figure 9. Projected\% change in grain yield using CERES-Maize model in 2040-2069/1980-2010: (a) Baseline grain yield; (b) 2050 grain yield at RCP4.5; (c) 2050 grain yield at RCP8.5

\subsubsection{Reliability of Predicted Maize Grain Yield}

The average temperature change under RCP4.5 $(\mathrm{SD}=-0.09)$ shows higher risks that are linked to climate change. However, rainfall changes at RCP8.5 ( $\mathrm{SD}=-2.81)$ scenario shows higher risks linked to climate change. The standard deviation (SD) and mean grain yield for the baseline (0.40-1.42) and future scenarios are shown in Table 2. As explained above, the grain yields were predicted to reduce during the 2050s. The standard deviation, an indicator of uncertainty and variability, was predicted to decrease under the RCP4.5 (0.27-0.83) and RCP8.5 (0.43-0.89). Cultivar PHB30G19 shows the least reliability followed by ZMS606 and PHB30G50 when yield from sowing dates and $\mathrm{N}$ rates are compared. However, the RCP8.5 scenario shows high unreliability. (Nkomozepi and Chung, 2013) noted that the trouble encountered in predicting accurately the potential impacts of climate change to grain yields adds to the unreliability. Lower rates of nitrogen fertilizer $\left(67.02 \mathrm{~kg} \mathrm{~N} \mathrm{ha}^{-1}\right)$ had smaller coefficient of variation and standard deviation that corresponded to low risks associated with change in temperature and rainfall. Cultivars receiving higher nitrogen fertilizer rates had higher coefficient of variation and exhibit high unreliability under future changed climate. 
Table 2. Standard deviation and mean maize biomass and grain yield for the baseline (1980-2010) and future (2040-2069) scenarios $\left(\mathrm{t} \mathrm{ha}^{-1}\right)$

\begin{tabular}{|c|c|c|c|c|c|c|c|c|c|c|c|c|}
\hline \multirow{2}{*}{ Treatment } & \multicolumn{4}{|c|}{ Baseline } & \multicolumn{4}{|c|}{ RCP4.5 } & \multicolumn{4}{|c|}{ RCP8.5 } \\
\hline & tops & $\mathrm{sd}$ & grain & $\mathrm{sd}$ & tops & $\mathrm{cV}$ & grain & $\mathrm{cv}$ & tops & $\mathrm{cV}$ & grain & $\mathrm{cv}$ \\
\hline PD1_ZMS606_N1 & 10.67 & 1.16 & 6.38 & 0.86 & 8.67 & 0.09 & 5.15 & 0.09 & 9.15 & 0.09 & 5.39 & 0.11 \\
\hline PD1_ZMS606_N2 & 10.83 & 1.70 & 6.45 & 1.39 & 8.56 & 0.09 & 4.65 & 0.14 & 9.08 & 0.09 & 5.16 & 0.13 \\
\hline PD1_ZMS606_N3 & 11.31 & 1.72 & 6.77 & 1.42 & 9.32 & 0.10 & 5.53 & 0.13 & 9.44 & 0.10 & 5.57 & 0.13 \\
\hline PD2_ZMS606_N1 & 10.67 & 1.16 & 6.38 & 0.86 & 8.64 & 0.08 & 5.13 & 0.09 & 9.15 & 0.09 & 5.39 & 0.11 \\
\hline PD2_ZMS606_N2 & 10.83 & 1.70 & 6.45 & 1.39 & 8.56 & 0.09 & 4.65 & 0.14 & 9.08 & 0.09 & 5.16 & 0.13 \\
\hline PD2_ZMS606_N3 & 11.31 & 1.72 & 6.77 & 1.42 & 9.32 & 0.10 & 5.53 & 0.13 & 9.44 & 0.10 & 5.57 & 0.13 \\
\hline PD3_ZMS606_N1 & 10.67 & 1.16 & 6.38 & 0.86 & 8.64 & 0.08 & 5.13 & 0.09 & 9.15 & 0.09 & 5.39 & 0.11 \\
\hline PD3_ZMS606_N2 & 10.83 & 1.70 & 6.45 & 1.39 & 8.56 & 0.09 & 4.65 & 0.14 & 9.08 & 0.09 & 5.16 & 0.13 \\
\hline PD3_ZMS606_N3 & 11.31 & 1.72 & 6.77 & 1.42 & 9.32 & 0.10 & 5.53 & 0.13 & 9.44 & 0.10 & 5.57 & 0.13 \\
\hline PD1_P30G19_N1 & 11.31 & 1.14 & 6.40 & 0.94 & 8.83 & 0.08 & 5.10 & 0.11 & 9.64 & 0.10 & 5.42 & 0.16 \\
\hline PD1_P30G19_N2 & 10.86 & 1.58 & 5.91 & 1.17 & 8.38 & 0.12 & 4.26 & 0.19 & 9.29 & 0.09 & 4.84 & 0.16 \\
\hline PD1_P30G19_N3 & 11.26 & 1.41 & 6.08 & 1.04 & 9.25 & 0.09 & 5.00 & 0.16 & 10.01 & 0.10 & 5.51 & 0.16 \\
\hline PD2_P30G19_N1 & 11.31 & 1.14 & 6.40 & 0.94 & 8.83 & 0.08 & 5.10 & 0.11 & 9.64 & 0.10 & 5.42 & 0.16 \\
\hline PD2_P30G19_N2 & 10.86 & 1.58 & 5.91 & 1.17 & 8.38 & 0.12 & 4.26 & 0.19 & 9.29 & 0.09 & 4.84 & 0.16 \\
\hline PD2_P30G19_N3 & 11.26 & 1.41 & 6.08 & 1.04 & 9.25 & 0.09 & 5.00 & 0.16 & 10.01 & 0.10 & 5.51 & 0.16 \\
\hline PD3_P30G19_N1 & 11.31 & 1.14 & 6.40 & 0.94 & 8.83 & 0.08 & 5.10 & 0.11 & 9.64 & 0.10 & 5.42 & 0.16 \\
\hline PD3_P30G19_N2 & 10.86 & 1.58 & 5.91 & 1.17 & 8.38 & 0.12 & 4.26 & 0.19 & 9.29 & 0.09 & 4.84 & 0.16 \\
\hline PD3_P30G19_N3 & 11.26 & 1.41 & 6.08 & 1.04 & 9.25 & 0.09 & 5.00 & 0.16 & 10.01 & 0.10 & 5.51 & 0.16 \\
\hline PD1_P30B50_N1 & 10.60 & 0.79 & 6.64 & 0.40 & 8.60 & 0.07 & 5.20 & 0.05 & 9.44 & 0.07 & 5.91 & 0.07 \\
\hline PD1_P30B50_N2 & 11.66 & 1.14 & 7.95 & 0.93 & 9.32 & 0.08 & 6.10 & 0.12 & 9.87 & 0.09 & 6.48 & 0.11 \\
\hline PD1_P30B50_N3 & 11.90 & 1.24 & 8.04 & 1.04 & 9.44 & 0.08 & 6.01 & 0.11 & 9.76 & 0.09 & 6.26 & 0.10 \\
\hline PD2_P30B50_N1 & 10.60 & 0.79 & 6.64 & 0.40 & 8.60 & 0.07 & 5.20 & 0.05 & 9.44 & 0.07 & 5.91 & 0.07 \\
\hline PD2_P30B50_N2 & 11.66 & 1.14 & 7.95 & 0.93 & 9.32 & 0.08 & 6.10 & 0.12 & 9.87 & 0.09 & 6.48 & 0.11 \\
\hline PD2_P30B50_N3 & 11.90 & 1.24 & 8.04 & 1.04 & 9.44 & 0.08 & 6.01 & 0.11 & 9.76 & 0.09 & 6.26 & 0.10 \\
\hline PD2_P30B50_N1 & 10.60 & 0.79 & 6.64 & 0.40 & 8.60 & 0.07 & 5.20 & 0.05 & 9.44 & 0.07 & 5.91 & 0.07 \\
\hline PD2_P30B50_N2 & 11.66 & 1.14 & 7.95 & 0.93 & 9.32 & 0.08 & 6.10 & 0.12 & 9.87 & 0.09 & 6.48 & 0.11 \\
\hline PD2_P30B50_N3 & 11.90 & 1.24 & 8.04 & 1.04 & 9.44 & 0.08 & 6.01 & 0.11 & 9.76 & 0.09 & 6.26 & 0.10 \\
\hline
\end{tabular}

Note. sd: standard deviation; cv: coefficient of variation; tops: biomass yield $\left(\mathrm{t} \mathrm{ha}^{-1}\right)$; grain: grain yield $\left(\mathrm{t} \mathrm{ha}^{-1}\right)$.

\section{Conclusion}

This study considered the impact of climate change, sowing date, cultivar and nitrogen fertilizer rate effect on maize yield and yield components. Future climate (2040-2069) scenarios for Mount Makulu indicate a hotter and drier climate. Seasonal rainfall based on multi-ensemble mean would reduce under RCP4.5 (JFM = $-0.81 \mathrm{~mm}$; $\mathrm{OND}=-3.62 \mathrm{~mm})$ and RCP8.5 $(\mathrm{JFM}=0.32 \mathrm{~mm}$; OND $=-4.92 \mathrm{~mm})$. However, the mean seasonal temperature would increase under both future climate scenarios (RCP4.5 and RCP8.5) relative to the baseline. An increase in temperature with corresponding reduction in rainfall would lead to a reduced number of DAP to anthesis and physiological maturity. The reduced number of DAP would reduce maize biomass and grain yield in 2040-2069/1980-2010.

Treatments receiving lower N rates (ZMS606 and PHB30B50) would out-perform those receiving higher $\mathrm{N}$ rates during the 2050s. Fertilizer treatment rate (N2) effect on ZMS606 and PHB30G19 would have higher reduction in grain yield compared to N1 and N2 at all sowing dates. Cultivar PHB30B50 with N3 would experience higher reduction in grain yield compared to N1 and N2. The PHB30G50 cultivar is specifically bred to be grown under irrigated conditions. The reduction in rainfall would have an impact on growth and yield of PHB30B50 at higher fertility compared to lower fertility. Lower rates of nitrogen fertilizer $\left(67.02 \mathrm{~kg} \mathrm{~N} \mathrm{ha}^{-1}\right)$ had smaller coefficient of variation and standard deviation that corresponded to low risks associated with change in temperature and rainfall. Cultivars receiving higher nitrogen fertilizer rates had higher coefficient of variation and exhibit high unreliability under future climate scenarios. The adaptation and mitigation strategies required to cope with the effects of climate change impacts on maize growth and yield include adjustment in sowing dates, nitrogen fertilizer application rates, management practice and breeding for genotypes that are resilient to climate change. 


\section{Acknowledgements}

The authors would like to thank the Agricultural Productivity Program for Southern Africa (APPSA) a World Bank funded project in Zambia for the financial support to carry out the field experiments used in this study.

\section{References}

Ababaei, B., Sohrabi, T., Mirzaei, F., \& Karimi, B. (2010). Evaluation of a Stochastic Weather Generator in Different Climates. Comput. Inf. Sci., 3, 217. https://doi.org/10.5539/cis.v3n3p217

Adhikari, U., Nejadhashemi, A. P., \& Woznicki, S. A. (2015). Climate change and eastern Africa : a review of impact on major crops. Food Energy Secur., 110-132. https://doi.org/10.1002/fes3.61

Alemaw, B. F., \& Simalenga, T. (2015). Climate Change Impacts and Adaptation in Rainfed Farming Systems: A Modeling Framework for Scaling-Out Climate Smart Agriculture in Sub-Saharan Africa. Am. J. Cli-mate Chang., 4, 313-329. https://doi.org/10.4236/ajcc.2015.44025

AMCEN. (2011). Adressing Climate Change Challenges in Africa: A Pratical Guide Towards Sustainable Development. African Union.

Araya, A., Hoogenboom, G., Luedeling, E., Hadgu, K. M., Kisekka, I., \& Martorano, L. G. (2015). Assessment of maize growth and yield using crop models under present and future climate in southwestern Ethiopia. Agric. For. Meteorol., 214, 252-265. https://doi.org/10.1016/j.agrformet.2015.08.259

Bassu, S., Brisson, N., Durand, J. L., Boote, K., Lizaso, J., Jones, J. W., ... Waha, K. (2014). How do various maize crop models vary in their responses to climate change factors? Glob. Chang. Biol., 1-29. https://doi.org/10.1111/gcb.12520

Bationo, A., Tabo, R., Kihara, J., Hoogenboom, G., Traore, P. C. S., Boote, K. J., \& Jones, J. W. (2012). Building Capacity for Modeling in Africa, Improving Soil Fertility Recommendations in Africa using the Decision Support System for Agrotechnology Transfer (DSSAT). Springer Netherlands, Dordrecht. https://doi.org/ 10.1007/978-94-007-2960-5_1

Butterworth, M. H., Semenov, M. A., Barnes, A., Moran, D., West, J. S., \& Fitt, B. D. L. (2009). North -South divide: Contrasting impacts of climate change on crop yields in Scotland and England. J. R. Soc. Interface, 1-8. https://doi.org/10.1088/1755-1307/6/37/372051

Chen, H., Guo, J., Zhang, Z., \& Xu, C. (2012). Prediction of temperature and precipitation in Sudan and South Sudan by using LARS-WG in future. Theor Appl Clim., 1-13. https://doi.org/10.1007/s00704-012-0793-9

Chisanga, C. B., Phiri, E., \& Chinene, V. R. N. (2017). Statistical Downscaling of Precipitation and Temperature Using Long Ashton Research Station Weather Generator in Zambia: A Case of Mount Makulu Agriculture Research Station. Am. J. Clim. Chang., 6, 487-512. https://doi.org/10.4236/ajcc.2017.63025

Chisanga, C. B., Phiri, E., Chizumba, S., \& Sichingabula, H. (2015). Evaluating CERES-Maize Model Using Planting Dates and Nitrogen Fertilizer in Zambia. J. Agric. Sci., 7, 1-20. https://doi.org/10.5539/jas.v7n3p79

Evans, N., Butterworth, M. H., \& Baierl, A. (2010). The impact of climate change on disease constraints on production of oilseed rape. Food Secur., 2, 143-156. https://doi.org/10.1007/s12571-010-0058-3

Fernandes, J. M., Lazzaretti, A., Pavan, W., \& Tsukahara, R. Y. (2011). Information architecture for crop growth simulation model applications. Int. Conf. Inf. Commun. Technol., 251-258.

Gaydon, D. S., Probert, M. E., Buresh, R. J., Meinke, H., \& Timsina, J. (2012). Modelling the role of algae in rice crop nutrition and soil organic carbon maintenance. Eur. J. Agron., 39, 35-43. https://doi.org/10.1016/ j.eja.2012.01.004

Hassan, Z., \& Harun, S., (2013). Impact of Climate Change on Rainfall Over Kerian, Malaysia With Long Ashton Research Station Weather Generator (LARS-WG). Malaysian J. Civ. Eng., 25, 33-44.

Hassan, Z., Shamsudin, S., \& Harun, S. (2014). Application of SDSM and LARS-WG for simulating and downscaling of rainfall and temperature. Theor. Appl. Climatol., 116, 243-257. https://doi.org/10.1007/ s00704-013-0951-8

Heydari, M., Noori, M., Sharifi, M. B., \& Zarghami, M. (2013). Utilization of LARS-WG Model for Modelling of Meteorological Parameters in Golestan Province of Iran. J. River Eng., 1, 1-5.

Hughes, D. A., Mantel, S., \& Mohobane, T. (2014). An assessment of the skill of downscaled GCM outputs in simulating historical patterns of rainfall variability in South Africa. Hydrol. Res., 45, 134. https://doi.org/10.2166/nh.2013.027 
IPCC. (2013). Climate Change 2013: The Physical Science Basis. Contribution of Working Group I to the Fifth Assessment Report of the Intergovern- mental Panel on Climate Change, Intergovernmental Panel on Climate Change, Working Group I Contribution to the IPCC Fifth Assessment Report (AR5). Cambridge University Press, Cambridge, United Kingdom and New York, NY, USA, Geneva, Switzerland. https://doi.org/10.1029/2000JD000115

Jones, C. A., \& Kiniry, J. R., (1986). CERES-Maize: A simulation model of maize growth and development. Texas A\&M University Press, College Station, Texas, Texas, USA.

Jones, J. W., Hoogenboom, G., Porter, C. H., Boote, K. J., Batchelor, W. D., Hunt, L. A., ... Ritchie, J. T. (2003). The DSSAT cropping system model. J. Agron., 18, 235-265. https://doi.org/10.1016/S1161-0301(02) 00107-7

Kang, Y., Khan, S., \& Ma, X. (2009). Climate change impacts on crop yield, crop water productivity and food security-A review. Prog. Nat. Sci., 19, 1665-1674. https://doi.org/10.1016/j.pnsc.2009.08.001

Keating, B. A., Wafula, B. M., \& McCown, R. L. (1988). Simulation of plant density effects on maize yield as influenced by water nitrogen limitations. Proceedings of the International Congress of Plant Physiology, February 15-20, 1988, New Delhi, India (pp. 547-559).

Khan, M. S., Coulibaly, P., \& Dibike, Y. (2006). Uncertainty analysis of statistical downscaling methods using Canadian Global Climate Model predictors. Hydrol. Process., 20, 3085-3104. https://doi.org/10.1002/ hyp. 6084

Lin, Y., Wu, W., \& Ge, Q. (2015). CERES-Maize model-based simulation of climate change impacts on maize yields and potential adaptive measures in Heilongjiang Province, China. J. Sci. Food Agric., 95, 2838-2849. https://doi.org/10.1002/jsfa.7024

Lizaso, J. I., Boote, K. J., Jones, J. W., Porter, C. H., Echarte, L., Westgate, M. E., \& Sonohat, G. (2011). CSM-IXIM: A New Maize simulation model for DSSAT version 4.5. Agron. J., 103, 766-779. https://doi.org/10.2134/agronj2010.0423

Lukeba, J.-C. L., Vumilia, R. K., Nkongolo, K. C. K., Mwabila, M. L., \& Tsumbu, M. (2013). Growth and Leaf Area Index Simulation in Maize (Zea mays L.) under Small-Scale Farm Conditions in a Sub-Saharan African Region. Am. J. Plant Sci., 4, 575-583. https://doi.org/10.4236/ajps.2013.43075

Manyeruke, C., \& Mhandara, L. (2013). The Effects of Climate Change and Variability on Food Security in Zimbabwe: A Socio-Economic and Political Analysis. Int. J. Humanit. Soc. Sci., 3, 270-286. https://doi.org/ 10.5296/jpag.v3i1.3379

Mckague, K., Rudra, R., Ogilvie, J., Ahmed, I., \& Gharabaghi, B. (2005). Evaluation of Weather Generator ClimGen for Southern Ontario. Can. Water Resour. J., 30, 315-330. https://doi.org/10.4296/cwrj3004315

MTENR. (2010). National Climate Change Response Strategy (NCCRS) Ministry of Tourism, Environment and Natural Resources. Government of the Republic of Zambia, Lusaka, Zambia.

Nkomozepi, T. D., \& Chung, S.-O. (2013). Uncertainty of Simulated Paddy Rice Yield using LARS-WG Derived Climate Data in the Geumho River Basin, Korea. J. Korean Soc. Agric. Eng., 55, 55-63. https://doi.org/10.5389/KSAE.2013.55.4.055

Nurudeen, R. A. (2011). Decision Support System for Agro-technology Transfer (DSSAT) model sSimulation of maize growth and yield response to NPK fertilizer application on a benchmark soil of Sudan Savanna Agro-Ecological Zone of Ghana. Kwame Nkrumah University of Science and Technology Kumasi.

Osman, Y., Abdellatif, M., Aljawad, S. B., \& Knutsson, S. (2014). Expected Future Precipitation in Central Iraq using LARS-WG Stochastic Weather Generator. Engineering, 6(12), 948-959. https://doi.org/10.4236/ eng.2014.613086

Qian, B., Gameda, S., Hayhoe, H., Jong, R. de, \& Bootsma, A. (2004). Comparison of LARS-WG and AAFC-WG stochastic weather generators for diverse Canadian climates. Clim. Res., 26, 175-191. https://doi.org/10.3354/cr00755

Qian, B., Hayhoe, H., \& Gameda, S. (2005). Evaluation of the stochastic weather generators LARS-WG and AAFC- WG for climate change impact assessment. Clim. Res., 29, 3-21. https://doi.org/10.3354/cr029003

Qian, J.-H., Seth, A., \& Zebiak, S. (2003). Reinitialized versus Continuous Simulations for Regional Climate Downscaling. Monthly Weather Review, 131(11). https://doi.org/10.1175/1520-0493(2003)131\%3C2857: RVCSFR\%3E2.0.CO;2 
Racsko, P., Szeidl, L., \& Semenov, M. (1991). A serial approach to local stochastic weather models. Ecol. Modell., 57, 27-41. https://doi.org/10.1016/0304-3800(91)90053-4

Ruane, A. C., Goldberg, R., \& Chryssanthacopoulos, J. (2015). Climate forcing datasets for agricultural modeling: Merged products for gap-filling and historical climate series estimation. Agric. For. Meteorol., 200, 233-248. https://doi.org/10.1016/j.agrformet.2014.09.016

Semenov, M. A., \& Barrow, E. M. (2002). LARS-WG: A Stochastic Weather Generator for Use in Climate Impact Studies (Version 3, User Manual). Hertfordshire, UK.

Semenov, M. A., \& Brooks, R. J. (1999). Spatial interpolation of the LARS-WG stochastic weather generator in Great Britain. Clim. Res., 11, 137-148. https://doi.org/10.3354/cr011137

Semenov, M. A., \& Stratonovitch, P. (2010). Use of multi-model ensembles from global climate models for assessment of climate change impacts. Clim. Res., 41, 1-14. https://doi.org/10.3354/cr00836

Semenov, M. A., \& Stratonovitch, P. (2015). Adapting wheat ideotypes for climate change: Accounting for uncertainties in CMIP5 climate projections. Clim. Res., 65, 123-139. https://doi.org/10.3354/cr01297

Semenov, M. A., Brooks, R. J., Barrow, E. M., \& Richardson, C. W. (1998). Comparison of the WGEN and LARS-WG stochastic weather generators for diverse climates. Clim. Res., 10, 95-107. https://doi.org/ $10.3354 / \mathrm{cr} 010095$

Semenov, M. A., Jamieson, P. D., \& Martre, P. (2007). Deconvoluting nitrogen use efficiency in wheat: A simulation study. Eur. J. Agron., 26, 283-294. https://doi.org/10.1016/j.eja.2006.10.009

Semenov, M. A., Martre, P., \& Jamieson, P. D. (2009). Quantifying effects of simple wheat traits on yield in water-limited environments using a modelling approach. Agric. For. Meteorol., 149, 1095-1104. https://doi.org/10.1016/j.agrformet.2009.01.006

Sen, Z. (2010). Critical Assessment of Downscaling Procedures in Climate Change. Int. J. Ocean Clim. Syst., 1, 85-98. https://doi.org/10.1260/1759-3131.1.2.85

Soler, C. M.., Sentelhas, P. C., \& Hoogenboom, G. (2005). Thermal time for phenological development of four maize hybrids grown off-season in a subtropical environment. J. Agric. Sci., 143(2-3), 169-182. https://doi.org/10.1017/S0021859605005198

Soussana, J. F., Graux, A. I., \& Tubiello, F. N. (2010). Improving the use of modelling for projections of climate change impacts on crops and pastures. J. Exp. Bot., 61, 2217-2228. https://doi.org/10.1093/jxb/erq100

Thornton, P., \& Cramer, L. (2012). Impacts of climate change on the agricultural and aquatic systems and natural resources within the CGIAR's mandate (Working Paper No. 23). Copenhagen, Denmark.

Tsimba, R., Edmeades, G. O., Millner, J. P., \& Kemp, P. D., (2013). The effect of planting date on maize grain yields and yield components. F. Crop. Res., 150, 145-155. https://doi.org/10.1016/j.fcr.2013.05.028

Wang, Q. (2015). Linking APCC Seasonal Climate Forecasts to a Rice-Yield Model for South Korea (Research Report 2015-20). APEC Climate Center, South Korea.

Waongo, M., Laux, P., \& Kunstmann, H. (2015). Adaptation to climate change: The impacts of optimized planting dates on attainable maize yields under rainfed conditions in Burkina Faso. Agric. For. Meteorol., 205, 23-39. https://doi.org/10.1016/j.agrformet.2015.02.006

Wilby, R. L., \& Dawson, C. W. (2004). Using SDSM Version 3.1-A decision support tool for the assessment of regional climate change impacts (User Manual).

Wilby, R. L., Charles, S. P., Zorita, E., Timbal, B., Whetton, P., \& Mearns, L. O. (2004). Guidelines for Use of Climate Scenarios Developed from Statistical Downscaling Methods. IPCC Task Group on Data and Scenario Support for Impacts and Climate Analysis.

ZaAS. (2013). Adaptation of Zambian Agriculture to Climate Change-A Comprehensive Review of the Utilisation of the Agro-Ecological Regions. Lusaka, Zambia.

Zhang, Y., Zhao, Y., Chen, S., Guo, J., \& Wang, E. (2015). Prediction of Maize Yield Response to Climate Change with Climate and Crop Model Uncertainties. J. Appl. Meteorol. Climatol., 785-794. https://doi.org/ 10.1175/JAMC-D-14-0147.1 


\section{Copyrights}

Copyright for this article is retained by the author(s), with first publication rights granted to the journal.

This is an open-access article distributed under the terms and conditions of the Creative Commons Attribution license (http://creativecommons.org/licenses/by/4.0/). 